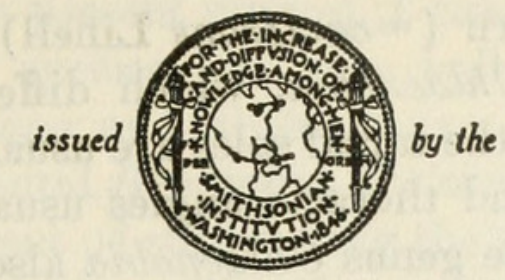

SMITHSONIAN INSTITUTION

U. S. NATIONAL MUSEUM

\title{
REVISION OF THE BEETLES OF THE MELOLONTHINE SUBGENUS PHYTALUS OF THE UNITED STATES
}

By Lawrence W. Saylor

Several years ago I began the study of the scarabaeid beetles of the subgenus Phytalus Erichson (genus Phyllophaga Harris) with the aim of bringing together in one paper data on all the described species, since the literature on the group is somewhat scattered and unavailable to many. It develops that several changes in taxonomic standing are necessary, and the knowledge of the distribution of the various species is greater than has been recorded. In this subgenus the genitalia of both sexes are of great use as supplementary diagnostic characters, and except in the case of Phyllophaga (Phytalus) omani Sanderson they have not been previously figured.

I am indebted to Dr. E. A. Chapin, Dr. M. A. Sanderson, Prof. E, C. Van Dyke, and Mark Robinson for the loan of material and for many other kindnesses.

The group as now defined is restricted to the American continents and adjacent islands and includes more than 60 described species, more than half of which inhabit Central America and the West Indies. In the United States the insects are found most commonly in the southern regions, specimens having been seen from Arizona, New Mexico, Texas, Georgia, Alabama, and Tennessee and also from New Jersey. I have recently received specimens of two of our United States species, $P$. pallida Horn and $P$. sonora Saylor (=debilis LeConte), from northern Mexico; a check of the literature reveals that these two species are apparently not recorded under any other name in Mexican faunal works. 
Phytalus vexatus Horn (=cavifrons Linell) has been removed by Chapin to the genus Chlaenobia, which differs from Phyllophaga (and Phytalus) in that the tarsal soles are usually very densely pilose in the male and the hind thoracic angles usually constricted rather abruptly at the base; the genus Chlaenobia also has a distinct facies, enabling one familiar with the group to recognize specimens on sight. Some of the true Listrochelus (e. g., scoparius) also have densely pilose soles in the male sex, and later studies may show that Chlaenobia may be better placed as a subgenus.

Phytalus is no longer tenable as a genus because some of the species exhibit characters that absolutely grade into those of Phyllophaga and leave no single character or group of characters distinguishing the two. Although it can no longer be used in a generic sense, the name Phytalus is of use subgenerically as applied to a group of species having narrowly cleft claws in at least the male sex.

In probably no other group of American scarab beetles is there such a variety of opinion as to the validity of genera and of their names as in that of the phyllophagans. In 1920 Arrow, of the British Museum, stated that Phytalus, Brahmina, and Holotrichia were not separable from Phyllophaga (=Lachnosterna), and with this I heartily agree, ${ }^{1}$ as I have found by experience that the use of the claws alone for generic characters is in most instances unsatisfactory because the claws may be very different in species that in every other character are obviously of the same genus.

In Phyllophaga, as at present recognized, there are several good groups, which, if segregated as different genera, however, would separate species greatly alike in most characters and apparently of the same lineage. Such a separation would, in most instances, be on the basis of the male characters alone, certainly undesirable criteria for generic definitions. Among such characters are the deformed middle claws, fixed hind tibial spurs, and narrowly cleft tarsal claws; the first two are nonvariable, but the last varies greatly in degree in the sexes. Another group could be defined if the very long basal claw dilation, giving the appearance of a third tooth, were used; in the single species concerned, $P$. heteronycha Bates, the tarsal claws of the fore and midlegs are 3-toothed, while those of the hind pair, like those of Phytalus, are narrowly cleft. Such a segregation is unadvisable, however, as all degrees in length of the tooth formed by the basal dilation can be found in various species. Furthermore, in my opinion it would serve no useful purpose to form a special genus for those species in which the usual three segments of the antennal club are increased to four or five, as other characters are the same as in the species with the normal number of segments in the club.

${ }^{2}$ See Revista Ent., vol. 7, fasc. 2-3, pp. 318-322, 1937. 
In the course of the present studies, I examined nearly every one of the United States species and also well over a 100 species of Neotropical Phyllophaga and allied genera, and in addition more than 50 species of Oriental Brahmina, Holotrichia, and allied groups. The necessity is apparent of suppressing the name Brahmina entirely and of ranking the American Phytalus and the Oriental Holotrichia as subgenera of Phyllophaga. This action has been suggested at one time or another, in whole or in part, by nearly every serious student of the group from Blanchard's time on (Blanchard, Bates, Arrow, Chapin, and Saylor), and the change was finally made by me in a recent paper (see footnote 1 ).

The position of other related genera, Listrochelus and Chirodines, is also open to some question; the former name seems to be valid for subgeneric use if restricted to a certain group of species, as has been done in a revision now in preparation by Dr. E. A. Chapin and myself. The genus Chirodines was separated on the basis of only a slight difference in the claws, and when thoroughly studied may quite possibly be shown to merit only subgeneric status, or may entirely fail of recognition.

Little is known regarding the economic status of the majority of the species, but $P$. pallida Horn has been observed doing a good deal of damage in Arizona by eating the foliage of rose bushes, young fruit trees, and walnut trees, often stripping them.

If the subgenus Phytalus is restricted to those species of Phyllophaga having the very narrowly cleft tarsal claws, it embraces the following species in our fauna: $P$. bilobatata Saylor, $P$. georgiana Horn, $P$. omani Sanderson, $P$. pallida Horn, P. sandersonia Saylor, $P$. sonora Saylor, and $P$. obsoleta vanalleri Schaeffer. The males usually have a flat or convex abdomen, as viewed from the side, and the antennal club is as long or nearly as long as the funicle; the females usually have the abdomen concave and robust and the antennal club much shorter than the funicle. 


\section{KEY TO THE SPECIES OF THE SUBGENUS PHYTALUS}

MALES

1. Hind tibiae with 1 spur free, the other fixed and immovable

Both hind tibial spurs free, movable

2. Upper tooth of claw longer to very much longer than lower one; antennae 9-segmented

Upper tooth much shorter and narrower than lower tooth; antennae 10-segmented.

sandersonia

3. Yellow-testaceous; scutellum distinctly punctured only at sides; lower tooth of claw two-thirds or more as long as upper; fixed spur of hind tibia directly contiguous with tibial margin.

omani

Rufotestaceous; scutellum evenly punctured over entire surface; lower claw tooth shorter; not more than one-half as long as upper; entire apical margin or posterior tibia distinct.

4. Fifth abdominal segment flattened at middle and coarsely punctate, not granulate; color reddish brown to piceous______. bilobatata

Fifth abdominal segment lobate or with granular tumosities

5. Upper tooth of claw much shorter than lower, claw very wide at base; fifth abdominal segment with a large triangularly shaped lobe, the latter incised at apex and projecting back over sixth segment.

Upper tooth of claw much longer than lower, fifth abdominal segment without a triangular lobe

6. Lobe of fifth abdominal segment reaching to or beyond apical margin, granulate, faintly bilobed at apex; pygidium coarsely rugose-punctate

Lobe of fifth abdominal seginent less evident, the surface more tumid, with transverse granules; pygidium smooth, sparsely punctured.

\section{FEMALES}

1. Pygidium with a distinct tubercle just above apex

Pygidium without tubercle, plane or sometimes thickened apically

2. Densely clothed above with short, erect, tawny hairs; thorax regularly and densely punctured, the punctures practically touching one another

Pronotum and elytra nearly or quite glabrous; thorax sparsely punctured, the punctures separated by 2 to 4 times their diameters

3. Lateral thoracic margins distinctly crenulate; claws narrowly cleft, upper tooth longer than lower; front very closely, coarsely rugose-punctate

Lateral thoracic margins entire or nearly so

4. Clypeus narrowly and deeply emarginate; color dark castaneous to rufopiceous

Clypeus broadly but not deeply emarginate; color testaceous or rufotestaceous

5. Last abdominal segment almost flat, slightly transversely sulcate; pygidium densely or sparsely punctured (Eastern United States) 
Last abdominal segment convex, not sulcate; pygidium sparsely punctured (Arizona, Mexico)

sonora

6. Scutellum densely, closely punctured; pygidium evenly punctured georgiana

Scutellum punctured only at sides; pygidium irregularly punctured omani

\section{PHYLLOPHAGA (PHYTALUS) SANDERSONIA, new name}

\section{Plate 9, Figures $1 a-1 c$}

Phytalus robustus HoRN, Trans. Amer. Ent. Soc., vol. 12, p. 120, 1895 (nec LeConte, 1856).

Phytalus trichodes Bates, Biologia Centrali-Americana, vol. 2, pt. 2, p. 178. 1890.

Male.-Robust, elongate-oval, rufocastaneous, shining, entirely clothed above with short, very dense, suberect hair, that of front longer. Head with front exceedingly densely variolate-punctate, the punctures of moderate size and closely contiguous; clypeus punctured like front but less densely so, its apex moderately reflexed and slightly emarginate at middle. Antennae 10-segmented, club subequal to or very slightly longer than funicle. Thorax very regularly and extremely densely, evenly punctured over the entire surface; hind angles obtusely angulate; lateral margins almost evenly arcuate, crenulate, ciliate. Elytra very rugosely wrinkled, densely punctured, striae other than sutural weakly indicated. Pygidium with or without a very short longitudinal carina at center of basal margin, surface flattened near apex, evenly and densely punctured over the entire surface, with dense moderately long suberect hairs; apex subtruncate to subrounded. Abdomen polished, sparsely hairy, widely, shallowly and longitudinally concave at center; fifth segment plane, with moderately dense setigerous punctures at sides and apex; sixth two-thirds as long as fifth, more coarsely punctured and with longer erect hairs. Fixed spur of hind tibia short and twisted. All claws with upper tooth much shorter and more slender than lower. Front tarsi with segments 1 to 3 , inclusive, with the inner apical margin prolonged into a strong spine, this character most strongly marked in segment 1.

Female--Pygidium glabrous, sparsely punctured, declivate, and with a tubercle before apex; posterior tibial spurs free, elongate. (Amended from original description.)

Length, 17-20 mm. Width, 8.5-10 mm.

Remarks.-Horn described the species from the Rio Grande country near Matamoros, and I have seen two specimens (that were compared with the type) from Brownsville, Tex. (F. H. Snow and Charles Schaeffer), and also one male from Del Rio, Tex. (May 15, 1937, A. Meade). Described by Bates from Las Vigas, Veracruz 
Mexico, and seen by me from Jalapa and Monterrey in Mexico (June). A comparison of the external features and of the genitalia of a cotype of Bates' species with Horn's species proves the two are identical. This species, to date, has been very rare in the United States, and less than a dozen specimens in American collections are known to me as having been taken within our boundaries; it was cited by Bates as being rather numerous at Las Vigas, Veracruz. The species is named for my good friend Dr. M. W. Sanderson.

\section{PhYllophaga (PHYTALUS) OMANI Sanderson}

Plate 9, Figures $2 a-2 e$

Phyllophaga (Phytalus) omani Sanderson, Journ. Kansas Ent. Soc., vol. 10, p. 66, 1937.

Male.-Elongate, cylindrical, yellow-testaceous, the head piceous, surface shining. Head with front moderately and not closely punctured, the punctures separated by one to several times their own diameters; clypeus deeply marginate and moderately punctured; clypeal suture lightly impressed. Antennae 9-segmented, the club as long as the entire stem, unicolorous. Prothorax moderately, rather unevenly punctured, the punctures closer along the anterior and basal margins; sides parallel in basal half, then gradually rounded to apex; with an indistinct fuscous spot near the rounded lateral margins. Elytra punctured like thorax, somewhat rugose, costae except sutural obsolete. Pygidium rather strongly convex, finely and evenly punctured with a few short hairs at apex, remaining surface glabrous. Abdomen somewhat flattened at middle and with vague longitudinal impressions on segments 3 and 4 ; segment 5 plane; segment 6 slightly excavated at middle and with a small punctate elevation each side of middle. One of the spurs of the hind tibia short and fixed. Upper portion of the claw nearly as wide as lower and distinctly longer. Lower claw margin very finely and minutely, irregularly crenulate.

Female.-Club of antennae shorter than funicle; hind tibial spurs free; abdomen somewhat flattened at middle; pygidium transverse and evenly punctured. Otherwise similar to male.

Length, $14 \mathrm{~mm}$. Width, $6 \mathrm{~mm}$.

\section{EXPLANATION OF PLATES 9 AND 10}

1, Phyllophaga (Phytalus) sandersonia, new name; 2, P. (P.) omani Sanderson; 3, P. (P.) georgiana (Horn) ; 4, P. (P.) bilobatata, new name; $5, P$. (P.) pallida (Horn); 6, P. (P.) sonora, new name; $7, P$. (P.) obsoleta vanalleri (Schaeffer).

Letters indicate views, as follows: $a$, En face view of male genitalia ; $b$, side view of male genitalia ; $c$, tarsal claw; $d$, female genitalia ; $e$, en face-ventral view of male genitalia. 

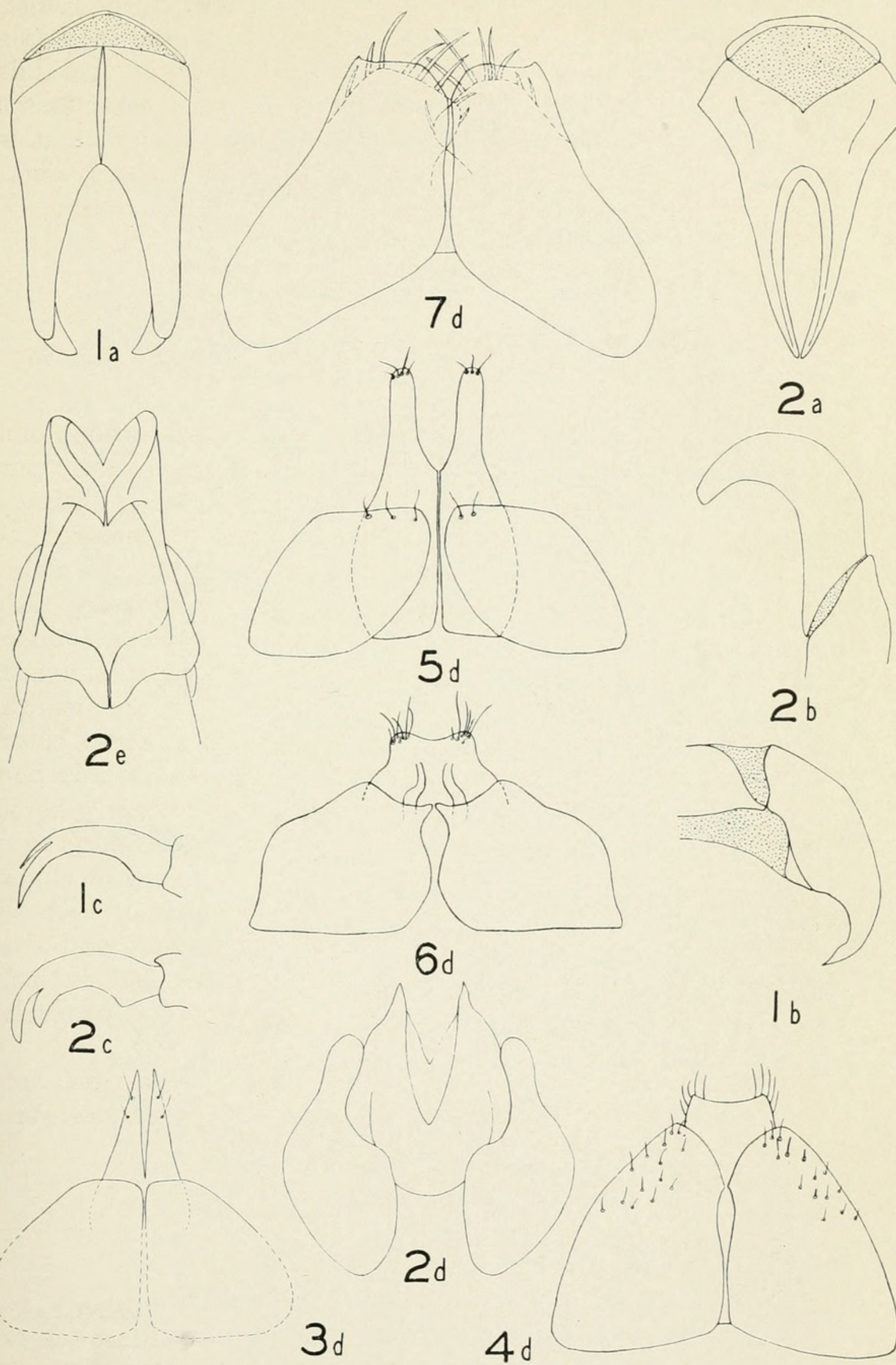

GENITALIA AND TARSAL CLAW OF PHYTALUS.

(FOR EXPLANATION OF PLATE SEE PAGE 162.) 

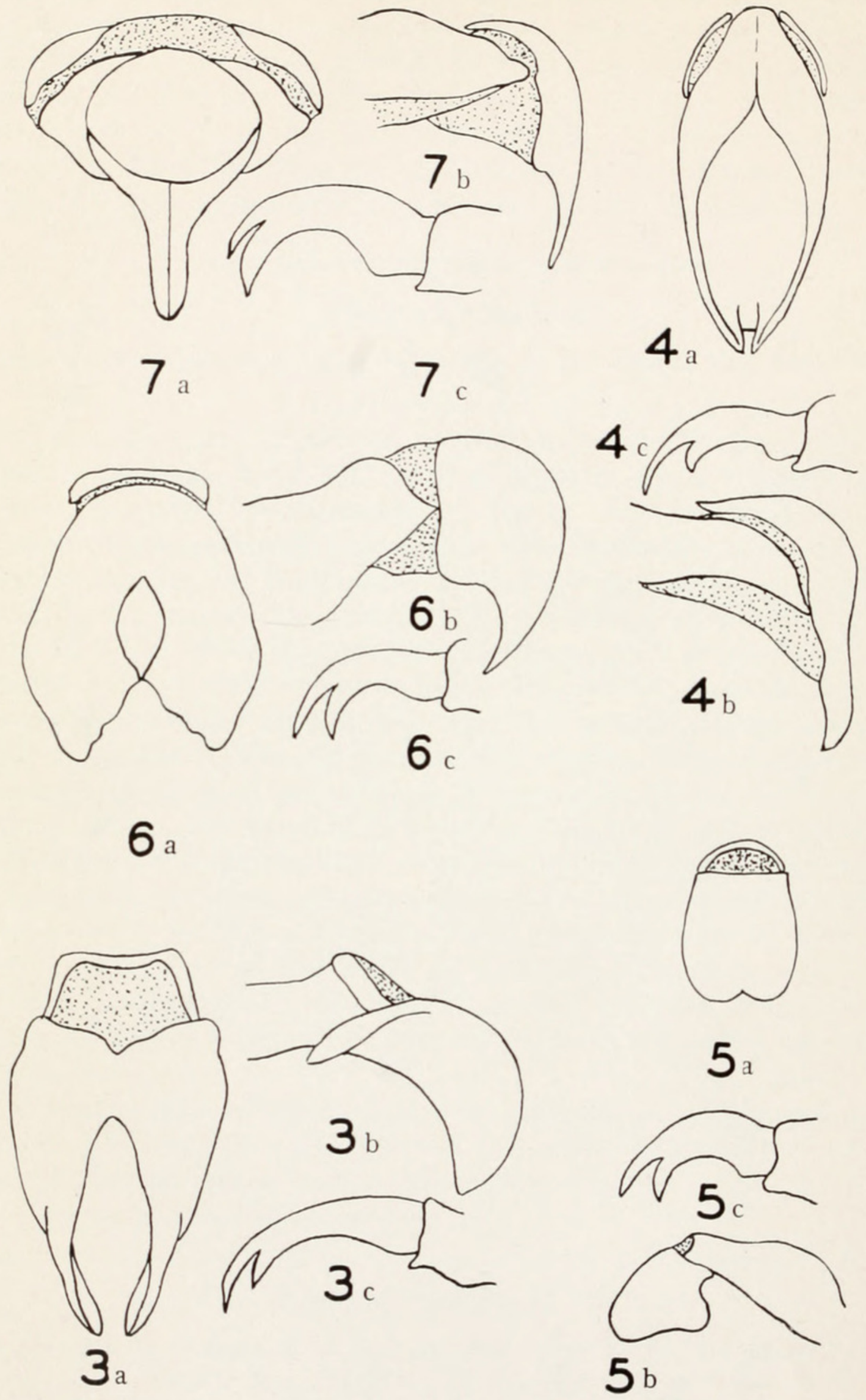

GENITALIA AND TARSAL CLAW OF PHYTALUS. (FOR EXPLANATION OF PLATE SEE PAGE 162.) 
Remarks.-This interesting species is known only from the type material; the above description is condensed from the original. The holotype and allotype are from Burnsville, Ala. (July 20, 1930), and Prattsburg, Ga. (July 24, 1930), respectively; through the courtesy of Dr. Sanderson I was allowed to examine the male type before its description. One male in my collection from "North America."

\section{PHYLLOPHAGA (PHYTALUS) GEORGIANA (Horn)}

Plate 9, Figure $3 d$; Plate 10, Figures $3 a-3 c$

Phytalus georgianus HoRn, Trans. Amer. Ent. Soc., vol. 12, p. 122, 1885.

Male.-Rufous to rufotestaceous, head and thorax darker, surface shining with a few short scattered hairs. Front of head coarsely punctured, slightly rugose, with a small very irregular impunctate area near the vertex; clypeal suture deeply impressed at sides only; clypeus coarsely rugose-punctate; apex acutely not deeply but rather broadly emarginate; antennal club slightly longer than remainder of the antennae, third and fourth segments elongate. Sides of thorax not crenulate, hind angles rectangular, front angles very obtuse, disk coarsely and densely variolate-punctate, a few minute hairs near middle of the base. Elytra densely and coarsely rugose-punctate. Pygidium very convex, rather densely and irregularly punctured, glabrous, apex broadly rounded. Abdomen flattened at middle, polished, with a few setigerous punctures; segment 5 much shorter than 6 , abruptly and narrowly declivate at apical margin; segment 6 slightly concave at center, with a transverse carina, the latter bearing a row of sparse hairs, and the row interrupted at middle. Hind tibial spurs spiniform, with the fixed one half as long as the other.

Female.-In the specimen at hand, the antennae are 8-segmented, with segment 3 very elongate, but it is probable that the normal number of segments is 9 ; club equal to segments $3-5$ combined; last abdominal segment very shallowly transversely sulcate, sparsely punctured and fimbriate at apex; tibial spurs elongate, free; otherwise similar to male.

Length, 12.5-13 mm. Width, 6-6.5 mm.

Remarks.-I have seen collected specimens from Whitesbog, N. J. (July 9), "Barcoure," Ala., and three bred specimens from Lakehurst, N. J.

Described from Georgia, this rather rare species is distinctly separated from the others by the sexual characters. Horn, in describing the species, apparently overlooked the fact that one hind tibial spur in the male is definitely fixed and immovable, though unless careful examination is made the spurs appear to be free. 


\section{PHYLlOPHAGA (PHYTALUS) OBSOLETA VANALLERI (Schaeffer)}

Plate 9, Figure $7 d$; Plate 10, Figure 7a-7c

Phytalus obsoletus Blanchand, Catalogue de la collection entomologique, vol. 1 , p. 131,1850 .

Phytalus vanalleri SchaEfFER, Bull. Brooklyn Ent. Soc., vol. '22, p. 215, 1927.

Male.-Elongate, subparallel, head and thorax rufous, otherwise testaceous to rufotestaceous, thorax and elytra glabrous, shining. Front of head closely, more or less confluently punctured, with long, erect, testaceous hair; a narrow area behind clypeal suture smooth and impunctate; clypeal suture not impressed; clypeus broad, faintly emarginate at middle of the subtruncate apex, the latter strongly reflexed, disk coarsely and sparsely punctured; antennal club usually longer than the rest of the antennae. Thoracic angles obtuse but well defined, base margined except at the middle, sides subangulate, subcrenulate; disk moderately, densely, and regularly umbilicate-punctate, with a small, irregular, median impunctate area; a few of the punctures with a minute testaceous hair. Elytra densely rugose-punctate, with a few hairs near apex. Pygidium very convex, polished, sparsely punctured, with suberect hairs; disk narrowly impressed before apex, the latter broadly rounded and ciliate. Abdomen shallowly impressed at middle, the concavity densely and finely setigerously punctate, the hair long and fine; segment 5 with a broad transverse carina near apical margin widely interrupted at middle, the carina densely pilose; segment 5 including the lobe as long as segments 3 and 4 combined; sides of abdomen sparsely punctured. Posterior spurs long, free.

Female.-Median impunctate area of thorax broader, with the punctures more distinct, middle of abdomen very slightly canaliculate, regularly and sparsely punctured, almost glabrous and highly polished; segment 5 more densely punctured at the slightly raised apical margin; segment 6 slightly convex, coarsely and sparsely punctured; antennal club equal to segments 3-7 combined; otherwise similar to male.

Length, 16-17 mm. Width, 7.5-8 $\mathrm{mm}$.

Remarks.-This form is rather uncommon in the Southeast, but specimens have been seen from Alabama, Texas, and Louisiana. It is easily separated from all others of our fauna by the sexual characters, and in these it is similar to $P$. obsoleta Blanchard, which is a common species in Mexico, Guatemala, and Nicaragua; the two are very close, and $P$. vanalleri $\mathrm{Sch}$ aeffer is probably best regarded at present as a northern subspecies having a longer antennal club (often two-fifths longer than the funicle), more crenate lateral thoracic margins, less elevated pectinate teeth on the lobe of the fifth abdominal 
segment, very sparsely punctured clypeus, and smoother front; individuals are not lacking, however, in which almost all intermediate degrees of these characters appear, and possibly when more specimens have been seen from northern Mexico and southeastern United States the name $P$. vanalleri Schaeffer may have to be withdrawn altogether.

The antennal club of $P$. vanalleri Schaeffer is very variable; in most specimens it is as long as or longer than the stem and scape combined, while in almost all specimens of typical $P$. obsoleta Blanchard the club is noticeably shorter than the scape and funicle combined (averages about one-fifth longer than the funicle) as well as being lighter in color. The clypeus of typical $P$. obsoleta Blanchard is almost always densely punctured, while that of $P$. vanalleri Schaeffer is sparsely punctured at the middle of the clypeal suture.

\section{PHYLLOPHAGA (PHYTALUS) BILOBATATA, new name}

\section{Plate 9, Figure 4d; Plate 10, Figures 4a-4c}

Phytalus cephalicus HonN, Trans. Amer. Ent. Soc., vol. 12, p. 120, 1885 (not cephalica LeConte, 1856).

Male.-Elongate, dark castaneous to piceous, shining, usually glabrous above. Head with front densely variolate-punctate; clypeal suture rather deeply impressed, slightly bisinuate; clypeus broad, deeply and very narrowly emarginate at apex, giving a bilobed appearance to the apical margin, surface slightly tumid in some examples, densely, coarsely, and somewhat confluently punctured; antennal club slightly smaller than the stem, antennae 10-segmented. Thorax with a faint suggestion of a longitudinal sulcus on the disk in some examples, sides obtusely rounded, hind angles obtuse but distinct, margin entire, disk finely, sparsely and rather regularly punctured, a more or less irregular smooth space at middle. Elytra moderately densely and rugosely punctured, sometimes with very minute testaceous hairs. Pygidiurn very convex, densely and rugosely punctured, the punctures each with a short hair; apex broadly rounded, with a few longer hairs. Abdomen convex, very sparsely and finely punctured at middle, segment 5 depressed behind, a small group of sparse, long, erect hairs on each side of the segment; segment 6 elevated, densely punctate, abruptly declivous at base, in some cases with a faint trace of a longitudinal impression. Posterior spurs long, narrow, and free.

Female.-Antennal club much smaller; abdomen more convex, last segment longer and less densely punctured; otherwise similar to male.

Length, 15-18 mm. Width, 6-7.5 mm.

Remarks.-All positively identified material is from Arizona; localities represented are Nogales, Carr Canyon, Fort Grant, and "Chiri- 


\section{$2 \mathrm{BHL}$ Biodiversity Heritage Library}

Saylor, Lawrence W. 1939. "Revision of the beetles of the melolonthine subgenus Phytalus of the United States." Proceedings of the United States National Museum 86, 157-167. https://doi.org/10.5479/si.00963801.86-3048.157.

View This Item Online: https://www.biodiversitylibrary.org/item/32496

DOI: https://doi.org/10.5479/si.00963801.86-3048.157

Permalink: https://www.biodiversitylibrary.org/partpdf/10644

\section{Holding Institution}

Smithsonian Libraries

\section{Sponsored by}

Smithsonian

\section{Copyright \& Reuse}

Copyright Status: NOT_IN_COPYRIGHT

Rights: https://www.biodiversitylibrary.org/permissions/

This document was created from content at the Biodiversity Heritage Library, the world's largest open access digital library for biodiversity literature and archives. Visit BHL at https://www.biodiversitylibrary.org. 